\title{
The Paradox of Cultural Decolonization through the Colonizer's Language in Achebe's Things Fall Apart
}

\author{
Abdulqawi A. S. Altobbai* \\ Department of English, College of Science and Humanities, Alquwaiiyah, Shaqra University, KSA \\ Department of English, Arts College, Taiz University, Yemen
}

*Corresponding Author: Abdulqawi A. S. Altobbai, Department of English, College of Science and Humanities, Alquwaiiyah, Shaqra University, KSA, Department of English, Arts College, Taiz University, Yemen

\begin{abstract}
An important area of concern in postcolonial studies is language. In order to redeem the culture, some African writers have emphasized the need to reclaim the pre-colonial languages and cultural modes. Writers like Achebe were only concerned with finding ways in which English could be refashioned and appropriated to meet the requirements of the new context and thus overcome the disjunction between the experience of place of the colonized and the alien medium used. Achebe in his appropriation of English wanted not only to depict his own set of experiences but more significantly to achieve cultural decolonization. What strategies and techniques has he followed to turn English, the colonizer's language into a means of cultural decolonization? The answer is what this paper attempts to provide by examining Things Fall Apart. In their studies of Achebe's novel, critics have examined the language's role in evoking the native culture. But the significant role Achebe's version of English played in making the novel an important endeavor in the cultural decolonization is what this paper attempts to explore.
\end{abstract}

Keywords: Achebe, Things Fall Apart, Decolonization, Language, African literature, Igbo proverbs

Chinua Achebe is the most renowned and influential African novelist. Though he was not the first African writer to write in English, he is considered the father of modern African literature in English. Unlike the writings of his predecessors, Achebe's novels, especially his most widely read Things Fall Apart, are marked with their novelty of style. They sought to counter the colonial discourse and to be different from the colonial literature not only in their ideas but also in their style.

The Eurocentric education Achebe received at the missionary school and at the University College of Ibadan was meant to produce a self-hating student who is full of admiration for the 'civilizing' Europeans. Talking about his growth as a writer, Achebe admits that in the secondary school

We should have immediately identified with the Africans, but this was impossible because the dice were loaded against them, the way the story was told, the way the author took sides. And being children, you could not perceive this; you simply didn't want the adventurers to be harmed by the savages! (Lindfors 112)

However, this identification with the oppressor and the passive acceptance of his version of the story did not go on with Achebe. Ironically, it was at Ibadan, where he was exposed to a great number of European texts presenting the same colonial version of the story that Achebe began to realize the politics of those texts:

... I think I grew in Ibadan in a way that pointed clearly in the direction of writing. That was the period when I was able to reassess what I had read and I had to go by at that point was the colonial novel written by white people about us...I think it is simply encountering myself in literature and becoming aware that that's not me, you see. A number of texts helped: one of them was Joyce Cary's Mister Johnson and I suppose one of them was Conrad's Heart of Darkness. There were a lot of other books not so well known and not worth remembering. But what I'm talking about is encountering the colonial ideology, for the first time in fiction, as something sinister and unacceptable. So if you add to them the weakness to stories anyway, 
you have possibilities, even the incitement to become a writer, somebody who will attempt to tell his own story. Because we all have a story in us, at least one story, I believe. So in my case Ibadan was the watershed, a turning point. (Lindfors 183-4)

So Achebe on many occasions talks of how the 'misrepresentation' and 'distortion' done by books like Joyce Cary's Mister Johnson and Joseph Conrad's Heart of Darkness provoked him to make it his mission to write and respond to such texts and rectify such distortions and misrepresentations. Therefore, it is extremely significant to read Achebe's novels which deal with the colonial encounter in relation to and in response to the colonial texts prevalent at that time. In Things Fall Apart, one of Achebe's main goals is to present the cultural richness of the Igbo people who are presented as normal human beings with their own strengths and weaknesses. Achebe also criticizes the colonial and missionary enterprises which were cataclysmic in the collapse of the native society and culture.

Achebe believes that art has a duty towards society and his duty as a writer is to educate his people, rectify the distortions and deconstruct the stereotypes about Africans disseminated by the colonialist texts. Today we can safely say that Achebe's avowed mission has been somewhat successfully achieved and his books are now much more popular than the books he set out to respond to. "If Okonkwo's act is an early shot against the colonial practice, Achebe's act is an early shot against colonialism as a body of knowledge" (Ngugi and Sahle 67). One of the reasons for Achebe's success is his brilliant refashioning of English in order to enable it to accommodate the African experience and use it to serve his own decolonizing purposes.

An important area of concern in postcolonial studies is language. In order to redeem the culture, some African writers have emphasized the need to reclaim the pre-colonial languages and cultural modes. Others see cultural syncretism as an inescapable feature of all postcolonial societies. In Africa somethe most resolute being Ngugi- believe that decolonization should be radical and this can be achieved only through a return to the pre-colonial languages and cultures. Others like Achebe have accepted English as an inescapable as well as a useful inheritance. Writers like Achebe were only concerned with finding ways in which English could be refashioned and appropriated to meet the requirements of the new context and thus overcome the disjunction between the experience of place of the colonized and the alien medium used. Achebe in his appropriation of English wanted not only to depict his own set of experiences but more significantly to achieve cultural decolonization. What strategies and techniques has he followed to turn English, the colonizer's language into a means of cultural decolonization? The answer is what this paper attempts to provide by examining Things Fall Apart. In their studies of Achebe's novel, critics have examined the language's role in evoking the native culture. But the significant role Achebe's version of English played in making the novel an important endeavor in the cultural decolonization is what is to be explored here.

Achebe's writings are prompted by his desire to initiate a discourse of resistance and to re-present the Africans as different from their stereotypes in colonialist discourse. Achebe was provoked by European writings which presented a "superficial picture" (Qtd. in Innes 18 ) of Africa. He took on himself the responsibility of rectifying the distorted image of Africa and Africans disseminated by the European writings. So his novel Things Fall Apart should be considered against the tyrannical discourse of colonialism.

To understand the novel properly one has to keep in mind the ways in which the colonial tradition represented Africa and the Africans. In the colonialist discourse against which Achebe has written, Africa is represented, as David Carroll says, as "a landscape without figures, an Africa without Africans" (Carroll 2). The Africans are seen as naturally inferior to the Europeans. According to Thomas Jefferson, the "blacks are inferior to the whites on the endowments of their body and mind" (Qtd. in Ngugi 18).

Achebe like most African writers is a committed writer. He says that the purpose of his novels is "to teach [his] readers that their past - with its imperfections- was not one long night of savagery from which the first Europeans - acting on God's behalf - delivered them" (Achebe, 1975: 45). So he takes it as his responsibility to counter the colonialist representation, rehabilitate the distorted culture and decolonize the Africans' minds and restore confidence in them.

Achebe is aware of the enormity of the task arising out of the use of the colonizer's language to affect a cultural decolonization. He accepts the "fatalistic logic of the unassailable position of English "(Qtd. in Ngugi 7) in the African literature and the only question that preoccupies him mind is how to 
"fashion out an English which is at once universal and able to carry his peculiar experience" (Achebe, 1975:61). He believes that "a good instinct [may] turn [a] limitation in language into a weapon of great strength" (Achebe, 1975:61), though conscious efforts are required for this purpose.

In Things Fall Apart Achebe has utilized the Igbo language structures, Igbo folklore and Igbo words to the fullest extent possible. One effective technique employed is using Igbo words; Achebe first introduces the words followed by their translations in English. Then he uses the Igbo words without their counterparts in English. This allows the Western reader to familiarize himself with Igbo culture without turning the text into a clumsy one. For instance, the first time the author refers to a hut, without the Igbo word $o b i$; then on page 14 he refers to it by "hut, or $o b i$ "; after that obi is used alone. The same technique is applied to chi or personal god. This is one of the ways Achebe allows the reader to familiarize himself with both the material and non-material culture of the Igbo people.

Another technique is the use of proverbs that are translated almost literally into English so that the text could keep as close as possible to the Igbo expression. Achebe prepares his readers for the large number of proverbs used in the novel when his narrator says that "Among the Ibo the art of conversation is regarded very highly, and proverbs are the palm-oil with which words are eaten" (Achebe 7). Indeed, the proverbs in Things Fall Apart are used not merely to evoke the Igbo culture but to foreground its richness and variety and to draw attention to the values of the Igbo society.

Characters throughout the whole novel and particularly in part one use proverbs, similes and idiomatic expressions in the normal course of their dialogue. These proverbs and similes show the uniqueness of the Igbo culture and the feel of the agricultural and hunting society. When Okonkwo was still a struggling young man, he went to Nwakibie, a wealthy man in Okonkwo's village to borrow yam seeds. Okonkwo in order to assure him that he would be able to pay back, explained to him how serious and diligent he was. To support that he cited the Igbo proverb "the lizard that jumped from the high iroko tree to the ground said he would praise himself if no one else did " (Achebe 21). Nwakibie replied that he could "tell a ripe corn from its look" (Achebe 22). Thus Achebe subdues the language not only to the Igbo milieu but also to his characters' ways of thinking, speaking their minds and expressing their attitudes. His characters' modes of thought and expression are foregrounded through the use of proverbs which also bring a clear picture of the Igbo culture in the reader's mind. The reader is "forced to become aware of a foreign reality which he must accept as different. Language encourages the reader to leave his natural propensity for ethnocentrism" (Durix 47)

Not only characters which use proverbs, similes and idiomatic expressions, the narrator also uses such devices which establish that he himself speaks from within the Igbo culture, and that his consciousness is shaped as well as steeped in the Igbo culture. The narrator uses many culture-specific similes and expressions. Okonkwo's fame has grown "like a bushfire in the harmattan" (Achebe 3); Okonkwo worked daily in his farm "from cockcrow until the chicken went to roost"(Achebe 13); before the wrestling match "the air shivered and grew tense like a tightened bow"(Achebe 49); Ikemefuna "grew rapidly like a yam tendril in the rainy season" (Achebe 52); Ekwefi , when her daughter was taken away by the priestess, "stood gazing in the direction of voices like a hen whose only chick has been carried away by a kite"(Achebe 102).

The narrator's use of similes and expressions derived from the Igbo environment makes his language closely related to the speech of his characters. This further consolidates the impression of a distinctive culture which has been profoundly shaped by the Igbo flora and fauna. It also makes the text rich with idioms that act as constant reminders of the peculiarity of the Igbo society and culture. This also helps place "the reader at the center of this traditional community [and] forces him to acknowledge its cultural specifities, its conceptions of time and social organization, its strength and weaknesses" (Durix 6).

The cultural oral tradition of the Igbo is foregrounded through a number of stories told throughout the novel. One cannot fail to feel the richness of the Igbo oral traditions as one reads stories like that of the Tortoise and the Birds told in great detail, or the story of the lizard that killed his mother or the story of the quarrel between the Sky and Earth. These stories, which are "womanish" in Okonkwo's opinion, juxtaposed with Okonkwo's "masculine stories of violence and bloodshed" (Achebe 53) reflect the richness and diversity of the Igbo oral tradition.

The tortoise which imposes himself as a spokesperson for the birds, speaks on their behalf but in the way that serves his own interests. He marginalizes the birds and takes advantage of them but his tricks 
are soon revealed. This tale acts as a myth that reminds us of what the colonizing power has done to the Africans. The Igbo oral tradition is forcefully presented as "the indigenous equal of the European literary tradition" (Ashcroft 126) upon which the African writer can base his fiction. This is a complete dismissal of the claim of Eurocentric criticism that the African writer had "no canons other than the Western ones to emulate" (Ascroft 127). The African literature is seen as an autonomous literature which has its own models and norms.

Proverbs also provide a grammar of values which can be considered the articles of the Igbo constitution and by which the deeds of individuals can be judged and evaluated. In the conversation between Obierika and Okonkwo, the "proverbs concerning the lizard and the bird emphasize the society's concern with individual achievement and physical survival, as well as its perception of man as one with nature, learning from it and constantly aware of it" (Innes and Lindfors 113). They also emphasize that success and social status among the Igbo are obtained only through hard work. The lazy and indolent have no right to them. The image of the African as a one who refuses to accept responsibility is totally dismissed here.

Some proverbs, though used by individuals, reflect deeply ingrained values and attitudes in the society as a whole. A common reader may find the Igbo society "ritualistic and rigid" but one does not fail to notice that it is in many ways "surprisingly flexible" (Innes and Lindfors 94). The flexibility of the Igbo society is seen not only in the fact that Igbo elders find a way out for Okonkwo to avoid killing the boy who calls him father or in the fact that the punishment inflicted on the violater of the Week of Peace has been reduced. It is more significantly reflected in many proverbs. For example, the proverb "Let the kite perch and the egle perch if one says no to the other, let his wing break" (Achebe 19) shows the extent to which the society can be flexible and tolerant. Though Okonkwo is the last to tolerate eagles and kites perching together, the elders of Umuofia are willing to tolerate Mr. Brown and his flock and even tell Mr. Smith, despite his outrageous intolerance, that he can stay if he wishes to worship his god. This refutes the stereotyped representation of the African as a savage who is given to passion and knows no values.

Another important device in appropriating English to 'bear the burden' of the African cultural experience is the use of the Igbo words - translated and untranslated. The retention of Igbo words such as $\mathrm{Obi}$, ilo, chi, and ndichie, though they are immediately followed or preceded by their translations is one of Achebe's means of insisting on the presence of the Igbo culture. For, as Gabriel Okara says, "from a word, a group of words, a sentence, and even a name in any African language, one can glean the social norms, attitudes and values of people" (Qtd. in Ngugi 8). Many Igbo words are retained untranslated. These words especially words like ekwe, udu, uri, nso-ani are deliberately used to convey the sense of the Igbo cultural distinctiveness. This device forces the reader into an active engagement with the horizons of the culture in which these terms have meaning. In general, the function of the Igbo words is to show the reader that the Igbo possess a language of their own, and that their culture ranging from every day surroundings and artefacts (obi, ilo) to complex religious and philosophical concepts (chi, agbala) is expressed through it. In other words, to make it clear that the Igbo are a full-fledged cultural community.

So we can say that in countering the colonialist stereotypes and clichés on Africa and Africans and presenting a counter image, Achebe's special use of English plays a significant role in subverting the European notions of the Africans and the African culture. Achebe's use of English for the purpose of decolonization marks an important and distinctive feature in the assertion of an African aesthetics which has its own parameters. Loading English with Igbo proverbs, similes and words shows that English as used by its native writers can not adequately convey the cultural experience of an African society. In showing this fact, Achebe subverts the notion of the superiority and adequacy of English and by extension, the western literary tradition. In using culture-specific idiomatic and rhetorical devices, the flavour of the African life and at the same time the stylistic features of African oral traditions are captured. This in turn shows that Achebe has succeeded in grafting his fiction onto "African traditional trunks" (Chinweizu 258). The African oral tradition is presented as a tradition which is as rich and varied as the European literary tradition. Yet it has its own distinct norms and models which make it an appropriate background African writers can draw upon.

We can see how Achebe's style has heavily borrowed from the native Igbo culture and how that helps him present his themes, especially those of cultural assertion, in a more powerful manner. Achebe does not have to tell us that the Igbo society had a rich culture and spiritual system that served them 
well. The reader gets the feel while reading his novels which are loaded with Igbo proverbs, vocabulary, imagery and tales. Achebe's works, especially Things Fall Apart, just give a concrete example that the culture presented is able to assert itself by providing a framework for the stories and is capable of defending itself with its own tools. Despite his missionary education and Christian family, Achebe is able to divest himself completely of the missionary education influence and practically demonstrate his immersion in the native culture.

Achebe managed not only to divest himself of the influence of the missionary and colonial education. In fact, he was able to turn his education and family background into a positive factor in his formation as a writer. Achebe did not only distinguish himself in terms of the themes he took up in his writings but also his unique and elegant style. Many African writers who underwent a similar disillusionment process could not get rid of the profound influence of the missionary and colonial education. Ngugi, for instance, deals with the same issues and concerns as Achebe's but the devices - including imagery and idioms - employed to present such issues betray the profound influence of his missionary education. Achebe's unique style and his 'special' English lend the narrative its authenticity. The use of oral traditions, local idioms, proverbs, imagery and metaphors gives his writings its African flavour which helps Achebe achieve his cultural goals.

\section{WORKS CITED}

[1] Achebe, Chinua. (1975). Morning Yet on Creation Day. London: Heinemann.

[2] Achebe, Chinua. (1994). Things Fall Apart. New York: Anchor Books.

[3] Ashcroft, Bill and others. (1989). The Empire Writes Back: Theory and Practice in Postcoloonial Literatures. London: Routledge.

[4] Carroll, David.(1980). Chinua Achebe: Novelist, Poet, Critic. London: Macmillan Press Ltd..

[5] Chinweizu, Jemie and others. (1980). Towards the Decolonization of African Literatur: African Fiction \& Poetry \& their critics. K.P.I..

[6] Durix, Jean-Pierre. (1987). The Writer Written: The Artist and Creation in the New Literatures in English. New York: Greenwood Press.

[7] Innes C. L. (1990). Chinua Achebe. Cambridge: Cambridge University Press.

[8] Innes, C. L. and Bernth Lindfors (eds). (1978). Critical Perspectives on Achebe. Washington: Three Continent Press.

[9] Lindfors, Bernth, (ed.). (1997). Conversations with Chinua Achebe. Jackson: UP of Mississippi.

[10] Ngugi wa Thiong'o and Eunice Njeri Sahle. (2004). "Hegel in African Literature: Achebe's Answer." Diogenes; 51: 63-67.

[11] Ngugi, Wa Thiongo. (1986). Decolonizing The Mind: The Politics of Language in African Literature. London: James Currey.

\section{AUTHOR'S BIOGRAPHY}

Abdulqawi A. S. Altobbai has an MA from Jamia Millia Islamia University (New Delhi, India) and $\mathrm{PhD}$ from Osmania University (Hyderabad, India). He is an assistant professor of English at the Department of English, Arts College, Taiz University, Yemen. At present, he is working at the Department of English, College of Science and Humanities, Alquwaiiyah, Shaqra University, KSA.

Citation: Abdulqawi A. S. Altobbai, "The Paradox of Cultural Decolonization through the Colonizer's Language in Achebe's Things Fall Apart" "International Journal on Studies in English Language and Literature (IJSELL), vol 8, no. 5, 2020, pp. 8-12. doi: http://dx.doi.org/10.20431/2347-3134.0805002.

Copyright: () 2020 Authors. This is an open-access article distributed under the terms of the Creative Commons Attribution License, which permits unrestricted use, distribution, and reproduction in any medium, provided the original author and source are credited. 